
\title{
is Research Square \\ Isolation and Screening for Ureolytic Bacteria from Bukilat Cave, Camotes Islands, Cebu
}

\section{Virjun Rae Nery}

University of the Philippines Cebu

Kenneth Joseph Bureros ( $\nabla$ kcbureros@g-mail.nsysu.edu.tw )

National Sun Yat-sen University https://orcid.org/0000-0003-4407-4768

\section{Short Report}

Keywords: microbially-induced calcite precipitation (MICP), urease activity, conductivity, bacterial isolation, 16S rRNA gene sequencing

Posted Date: July 7th, 2021

DOl: https://doi.org/10.21203/rs.3.rs-660148/v1

License: (1) This work is licensed under a Creative Commons Attribution 4.0 International License. Read Full License 


\section{Abstract}

Microbial-induced calcite precipitation (MICP) is an eco-friendly technique used in creating better soil substrate often for engineering purposes. This is done through the application of the ureolytic pathway of certain bacteria. This study aims to discover whether any of these bacteria can be found in Bukilat Cave, Camotes Islands, Cebu. Samples from the pools of water, drip water, and swabs of the walls of the cave were collected, cultured, and then tested using Christensen's agar for their ability to undergo the ureolytic pathway. The rate at which they undergo the ureolytic pathway was then measured and compared between different sources and to the positive control, Bacillus megaterium. The results showed that there was no significant difference between the rate at which bacteria from the different sources underwent ureolysis. There was also no significant difference between the rate at which the collected bacteria underwent ureolysis and the rate of the positive control $(2.588 \mathrm{mM} / \mathrm{min})$. Finally, the species with the fastest rate of ureolysis was identified to be Bacillus cereus NR 074540 with a rate of $3.033 \mathrm{mM} / \mathrm{min}$. However, it is not ideal for MICP purposes because of its potential pathogenicity.

\section{Introduction}

The rise of our population and urbanization is accompanied by the need for infrastructure; more buildings, stronger, taller, able to house, or hold more people. These infrastructures consequently need a more stable and stronger ground to be built on. To improve the strength and stiffness of the soil, synthetic materials are injected into the subsurface. However, these synthetic materials are costly, difficult to distribute evenly, and may introduce hazardous materials into the environment (DeJong et al., 2010). Therefore, the employment of an alternative method, one more eco-friendly, becomes much more vital.

Calcium carbonate can help strengthen the substrate when integrated into the sand grains of the soil matrix. This can be done through a bio-geochemical process called MICP or microbial-induced calcite precipitation (Mortensen et al., 2011). This is achieved by microbes by making the subsurface environment more alkaline, thereby promoting calcium carbonate precipitation (Kohnhauser, 2007), which is done through bio-geochemical reaction networks such as urea hydrolysis, nitrate reduction, sulfate reduction, and iron reduction (DeJong et al., 2010).

MICP also has several other applications including removal of heavy metals and radionuclide (Arias et al., 2017) and carbon dioxide fixation (Dhami et al., 2013). As such, it is implied that these bacteria would be very useful in cleaning and stabilizing their respective environments. However, the rate at which these bacteria ureolyze determines how effective they will be in these processes (Dhami et al., 2017), moreover, some of these bacteria are considered pathogenic. So there is a need to properly and safely screen ureolytic bacteria to identify which bacteria can be used for MICP purposes.

This study aims to determine whether there are any bacteria capable of the ureolytic pathway, which contribute to MICP in the study site: Bukilat Cave on the island of Camotes, Cebu. Moreover, the study aims to demonstrate their ability to produce urease and initiate said pathway to create an alkaline 
environment that is a natural setting consequently allows the precipitation of calcium carbonate. And finally, this study aims to measure and compare the rate at which the bacteria species hydrolyze urea.

\section{Materials And Methods}

\section{Sample Collection and Preparation}

Water samples were collected from the pools in the cave $\left(10^{\circ} 39^{\prime} 34.8^{\prime \prime} \mathrm{N} 124^{\circ} 30^{\prime} 51.8^{\prime \prime} \mathrm{E}\right)$ and the drip water coming from the stalactites. Swab samples were also collected from the walls of the cave and kept in an isotonic solution. These samples were collected and stored in an icebox at $4^{\circ} \mathrm{C}$ until it was processed at the lab. In the lab, the samples were serially diluted and then cultured in nutrient agar with $5 \%$ urea solution added aseptically through the use of a syringe filter. The control strain, Bacillus megaterium PNCM 1890, was obtained from PNCM-BIOTECH, UPLB and was kept at $4^{\circ} \mathrm{C}$ until use.

\section{Christensen's Medium}

To confirm their ability to produce urease, urea agar base or Christensen's medium (HiMedia, India) was used (Omoregie et al., 2016). The agar was distributed into sterile test tubes, and each bacteria colony was introduced into individual test tubes and then incubated at $37^{\circ} \mathrm{C}$ for $72 \mathrm{~h}$. A color change was observed from pale yellow to pink-red for colonies that successfully initiated the ureolytic pathway. The same procedure was performed to the positive control for comparison. Following the methods of Omoregie and his colleagues (2016), only the samples that could successfully convert approximately 10 $\mathrm{mL}$ of the agar to pink-red were subjected to the next step.

\section{Conductivity Method}

Finally, to compare each colonies' rate of urease activity, the conductivity method employed by Omoregie and colleagues (2016) was followed. For enzyme assay, $1 \mathrm{~mL}$ of each cultured bacteria was added to 9 $\mathrm{mL}$ of $1.11 \mathrm{M}$ urea solution and the conductivity was recorded. An electrical conductivity meter (CDM210, France) was used for $5 \mathrm{~min}$ at $25^{\circ} \mathrm{C}$. Relative conductivity was then converted to urea hydrolysis rate using the formula: Urea hydrolyzed $(\mathrm{mM})=$ Conductivity $(\mathrm{mS} / \mathrm{cm} / \mathrm{min}) \times 11.11$ (Eq. 1, Whiffin, 2004).

\section{Bacteria identification}

A selected bacterial isolate that had the fastest rate of ureolysis was sent to Kinovett Scientific Solutions Co., Philippines for species identification. DNA extraction was done using a genomic DNA kit (Macrogen, South Korea). This was followed by PCR amplification using 27F 5' (AGA GTT TGA TCM TGG CTC AG) 3' and 1492R 5' (TAC GGY TAC CTT GTT ACG ACT T) 3', while the primers used for sequencing were 785F $5^{\prime}$ (GGA TTA GAT ACC CTG GTA) 3'and 907R 5' (CCG TCA ATT CMT TTR AGT TT) 3'. The PCR amplification conditions were as follows: an initial denaturation step at $95^{\circ} \mathrm{C}$ for $5 \mathrm{~min} ; 30$ cycles of denaturation at $95^{\circ} \mathrm{C}$ for $30 \mathrm{~s}$, annealing at $55^{\circ} \mathrm{C}$ for $2 \mathrm{~min}$, and extension at $68^{\circ} \mathrm{C}$ for $1.5 \mathrm{~min}$; and a final extension step at $68^{\circ} \mathrm{C}$ for $10 \mathrm{~min}$. Sequencing were performed by using Big Dye terminator cycle sequencing kit v.3.1 
(Applied BioSystems, USA). Sequencing products were resolved on an Applied Biosystems model 3730XL automated DNA sequencing system (Applied BioSystems, USA) at Macrogen, Inc. Seoul, Korea.

\section{Data Analyses}

To test whether data is normally distributed, Shapiro-Wilk test was applied, and to verify its result, a Q-Q plot was also observed. Then, given that the sample size is small, a non-parametric test was applied to compare the different groups of data. To test whether there was any significant difference between the three sample groups and the positive control, the Kruskal-Wallis test was applied.

\section{Results And Discussion}

\section{Urease Activity}

When urea is hydrolyzed by urease released by bacteria, ammonia is released and increases the $\mathrm{pH}$ changing the color of the medium to pink-red (Omoregie et al., 2016). Following Omoregie and his colleagues (2016), only isolates that were able to change approximately $10 \mathrm{~mL}$ of the medium were chosen to be studied quantitatively based on their ability to produce urease quickly. In Fig. 1, the sample on the left was unable to react with the medium as much as the sample on the right. Of the cultures grown, only 24 were successful in converting $10 \mathrm{~mL}$ of the medium to pink-red: five colonies from the drip water sample, six colonies from the pool water, and 13 colonies from the cave wall swab samples.

\section{Rate of Urea Hydrolysis}

The conductivity method was first applied to the positive control and the $B$. megaterium was found to have a rate of urea hydrolysis of $2.588 \mathrm{mM} / \mathrm{min}$. The samples that passed the first test were then subjected to the conductivity test which would be able to quantify the amount of urea hydrolyzed. According to Whiffin (2004), the rate of ureolysis can be calculated through the use of the relative conductivity of a solution by using a formula (Eq. 1) they developed via a standard curve generated from the conductivity change in the complete hydrolysis of several concentrations of urea using purified urease.

The six species that tested positive from the pool waters of the cave were subjected to the conductivity method and consequently produced the rates seen in Fig. 2 . The species with the slowest rate was isolate P3S1 at $2.351 \mathrm{mM} / \mathrm{min}$ and the fastest was isolate P5S3 at $2.918 \mathrm{mM} / \mathrm{min}$. Shapiro-Wilk test was used to show that the samples were normally distributed. However, given that the sample size was very small, a Q-Q plot was also employed. The Q-Q plot showed that the pool sample group deviated from the expected normal.

The cave wall swab samples (Fig. 3) had 13 isolates that tested positive for ureolytic activity; the most from the three groups. The species with the slowest rate was isolate S4S1 at $2.414 \mathrm{mM} / \mathrm{min}$ and the fastest was isolate S2S2 at $3.033 \mathrm{mM} / \mathrm{min}$. Shapiro-Wilk test was used to show that the samples were 
normally distributed. The Q-Q plot showed that the cave walls sample group deviated from the expected normal.

From the drip sample group, only five samples tested positive for the ureolytic activity and so only these five were subjected to the conductivity test and produced the rates found in Fig. 4. Isolate D3S2 had the slowest rate of ureolysis at $2.394 \mathrm{mM} / \mathrm{min}$, and isolate D4S1 ureolyzed the fastest at $2.602 \mathrm{mM} / \mathrm{min}$. The Shapiro-Wilk test was used again to show that the samples were normally distributed. However, a Q-Q plot was also employed because the samples were small sample size. The plot showed that the sample deviated from the expected normal. Moreover, the boxplot (Fig. 5) showed that the drip group had two outliers: isolate D3S2 and isolate D4S1.

Statistical analysis shows that each group of data is normally distributed (Fig. 5). However, the Q-Q plot showed that the samples deviated from the normal output and so a nonparametric statistical analysis was used. Moreover, the data from the drip water samples have two outliers which may affect a parametric statistical analysis.

To compare the samples, the Kruskal-Wallis test was applied to determine whether there was a significant difference between the three groups of data and the positive control. Based on the results, there was no significant difference between the groups $(p=0.472, p>0.05)$. So, it can be said that the bacteria collected from Bukilat Cave all have statistically similar rates of ureolysis, which is considered relatively slow. Other species such as Sporosarcina pasterurii, which is often used as a positive control, have reported a range of 2.2 to $13.3 \mathrm{mM}$ urea hydrolyzed/min (Omoregie et al., 2016).

\section{Identity of Ureolytic Bacterium}

Finally, the sample earlier labeled as S2S2 having the fastest rate of ureolysis at $3.033 \mathrm{mM} / \mathrm{min}$, was identified as Bacillus cereus NR 074540. It is a Gram-positive, facultative anaerobic, motile, sporeforming, rod-shaped bacterium (Bottone, 2010). In bacteria, ureolysis is often done for two purposes; one is to provide ammonium for nitrogen metabolism, and two, to cope with acid stress (Mols and Abee, 2008). The study conducted by Mols and Abee (2008) found that $B$. cereus had relatively low ureolytic activity, compared to studies earlier conducted on Helicobacter pylori and Streptococcus salivarius, which they explained that $B$. cereus mainly undergoes ureolysis for nitrogen metabolism.

Certain species of urease-producing bacteria, including B. cereus, can therefore be found in Bukilat Cave, Camotes Islands, Cebu. Although this study shows that these species ureolyze at the same rates, more indepth studies can be done to explain why this may be. A study optimizing their rates of ureolysis through manipulation of several factors such as $\mathrm{pH}$, temperature, the addition of an organic source, etc., can also be done to see how this affects the species' rate of ureolysis. Future studies can also aim to identify more of the species found in caves to determine whether they are safe to use for MICP purposes or not. However, this study has shown that the bacteria found in Bukilat Cave, Camotes Islands, Cebu can ureolyze at the rate of at least $2.351 \mathrm{mM} / \mathrm{min}$ and may therefore have other applications such as metal sequestration (Dhami et al., 2013). 


\section{Declarations}

\section{ACKNOWLEDGEMENTS}

We thank the local government of Camotes Islands who allowed us to do sampling in Bukilat Cave.

\section{Funding}

Not applicable

\section{Conflicts of interest/Competing interests}

The authors declare no competing interests

Availability of data and material

Not applicable

Code availability

Not applicable

Authors' contributions

VR Nery concenptualized the study, conducted the experiments, analyzed the results, and written the paper. KJBureros assisted in conceptualizing the study, analyzed the results, and revising the paper.

\section{Ethics approval}

Not applicable

Consent to participate

Not applicable

Consent for publication

Not applicable

\section{References}

1. Arias D, Cisternas L, and Rivas M (2017) Biomineralization mediated by ureolytic bacteria applied to water treatment: a review. Crystals 7(11):345. https://doi.org/10.3390/cryst7110345

2. Bottone EJ (2010) Bacillus cereus, a volatile human pathogen. Clin Microbiol Rev 23(2): 382-398. http://doi.org/10.1128/cmr.00073-09 
3. DeJong JT, Mortensen BM, Martinez BC, and Nelson DC (2010) Bio-mediated soil improvement. Ecol Eng 36: 197-210. https://doi.org/10.1016/j.ecoleng.2008.12.029

4. Dhami NK, Reddy MS, and Mukherjee A (2013) Biomineralization of calcium carbonates and their engineered applications: a review. Front Microbiol 4:314. https://doi.org/10.3389/fmicb.2013.00314

5. Dhami NK, Alsubhi WR, Watkin E, and Mukherjee A (2017) Bacterial community dynamics and biocement formation during stimulation and augmentation: implications for soil consolidation. Front Microbiol 8:1267. https://doi.org/10.3389/fmicb.2017.01267

6. Kohnhauser K (2007) Introduction to Geomicrobiology. Malden, MA: Blackwell Publishing.

7. Mols M and Abee T (2008) Role of ureolytic activity in Bacillus cereus nitrogen metabolism and acid survival. Appl Environ Microbiol 74(8):2370-2378. http://doi.org/10.1128/aem.02737-07

8. Omoregie Al, Senian N, Li PY, Hei NL, Leong DOE, Ginjom IRH, Nissom PM (2016) Screening for urease-producing bacteria from limestone caves of Sarawak. BJRST 6(1):37-45. https://doi.org/10.33736/bjrst.213.2016

9. Whiffin VS (2004) Microbial $\mathrm{CaCO}_{3}$ precipitation for the production of biocement. Ph.D. Thesis. Murdoch University, Western Australia.

\section{Figures}




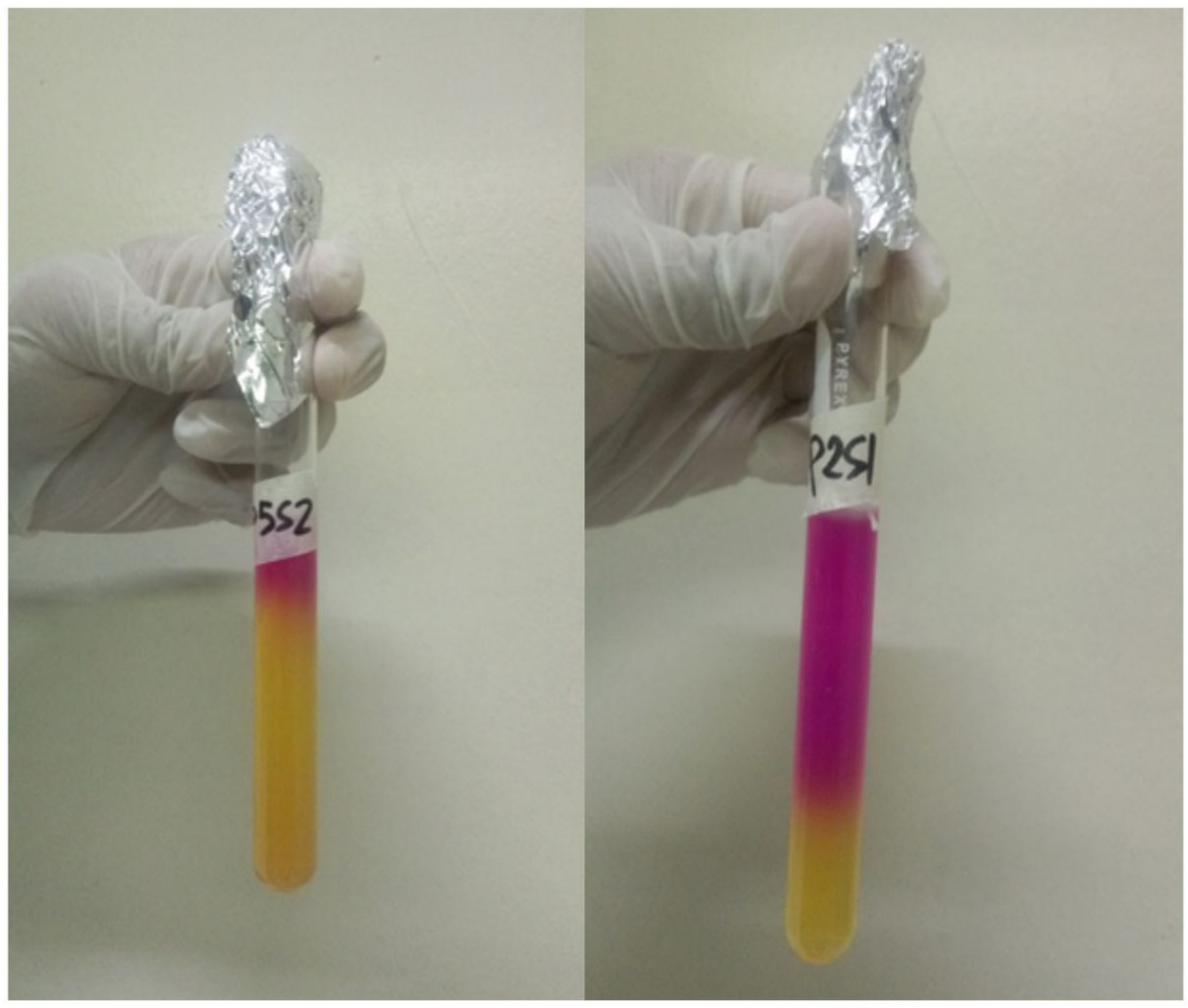

Figure 1

Samples cultured in Christensen's medium. 


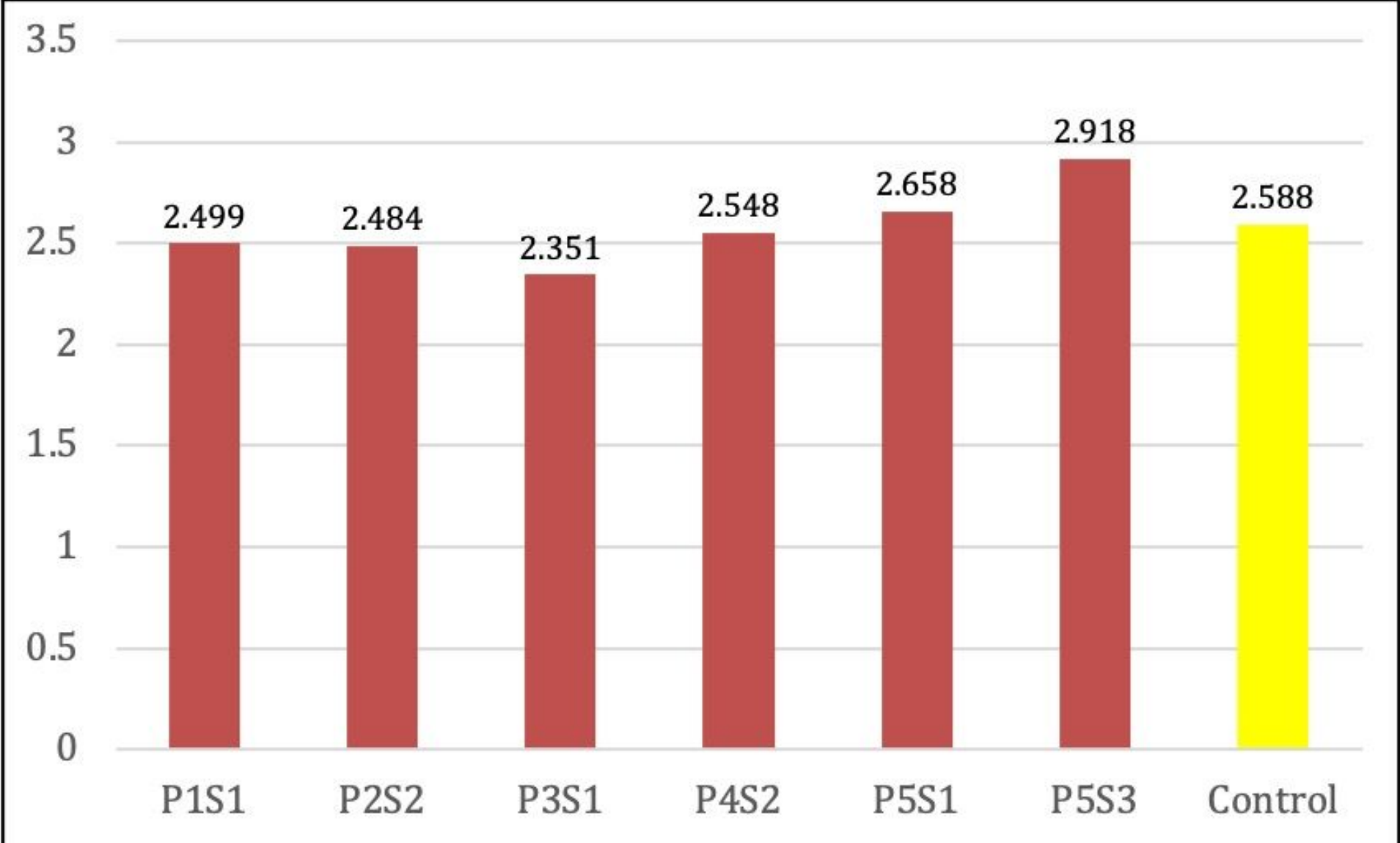

Figure 2

Rate of ureolysis of the species from the pools of Bukilat Cave, Camotes Islands, Cebu, and the positive control, B. megaterium. 


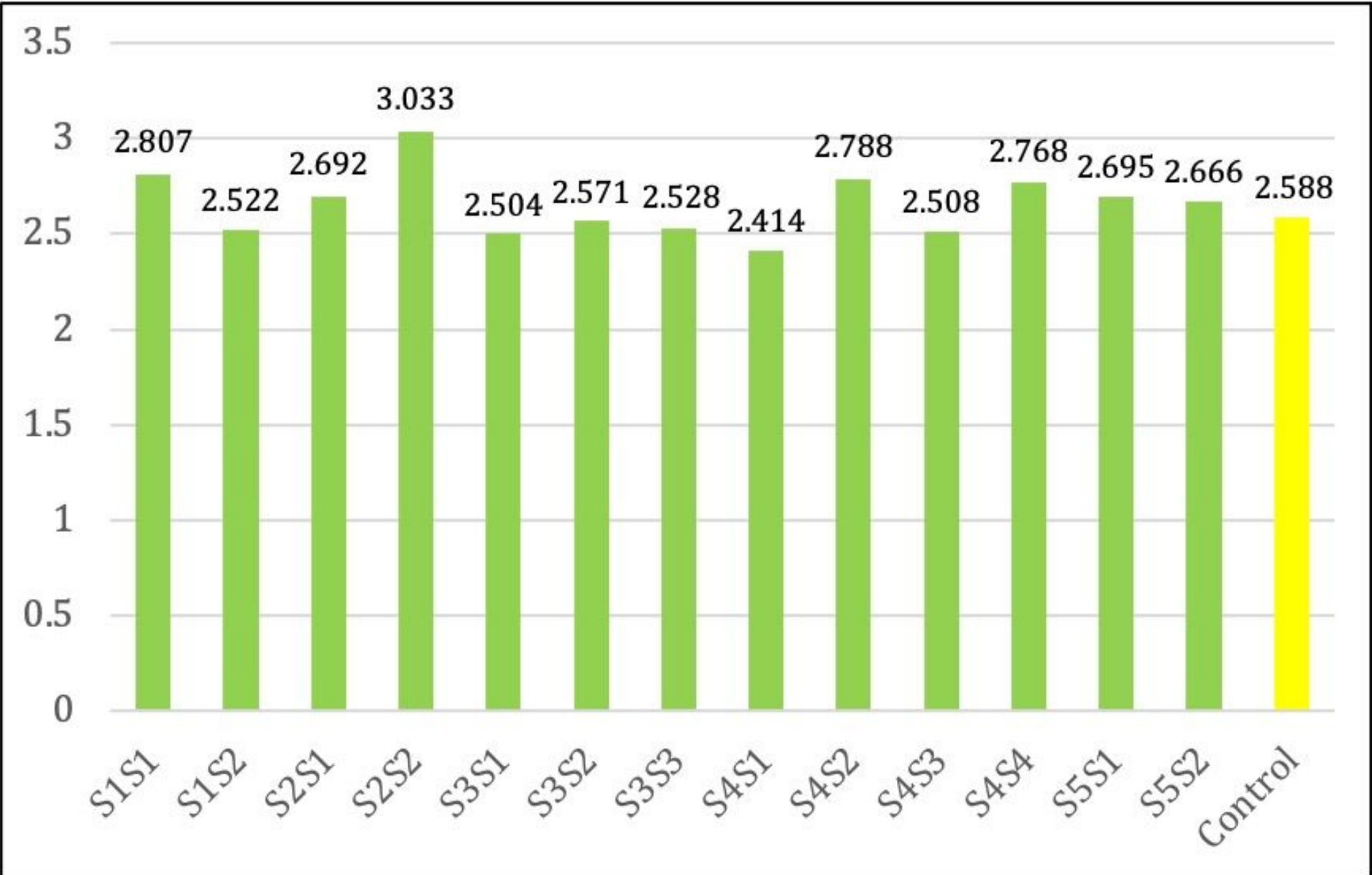

Figure 3

Rate of ureolysis of the species from the cave walls of Bukilat Cave, Camotes Islands, Cebu, and the positive control, B. megaterium. 


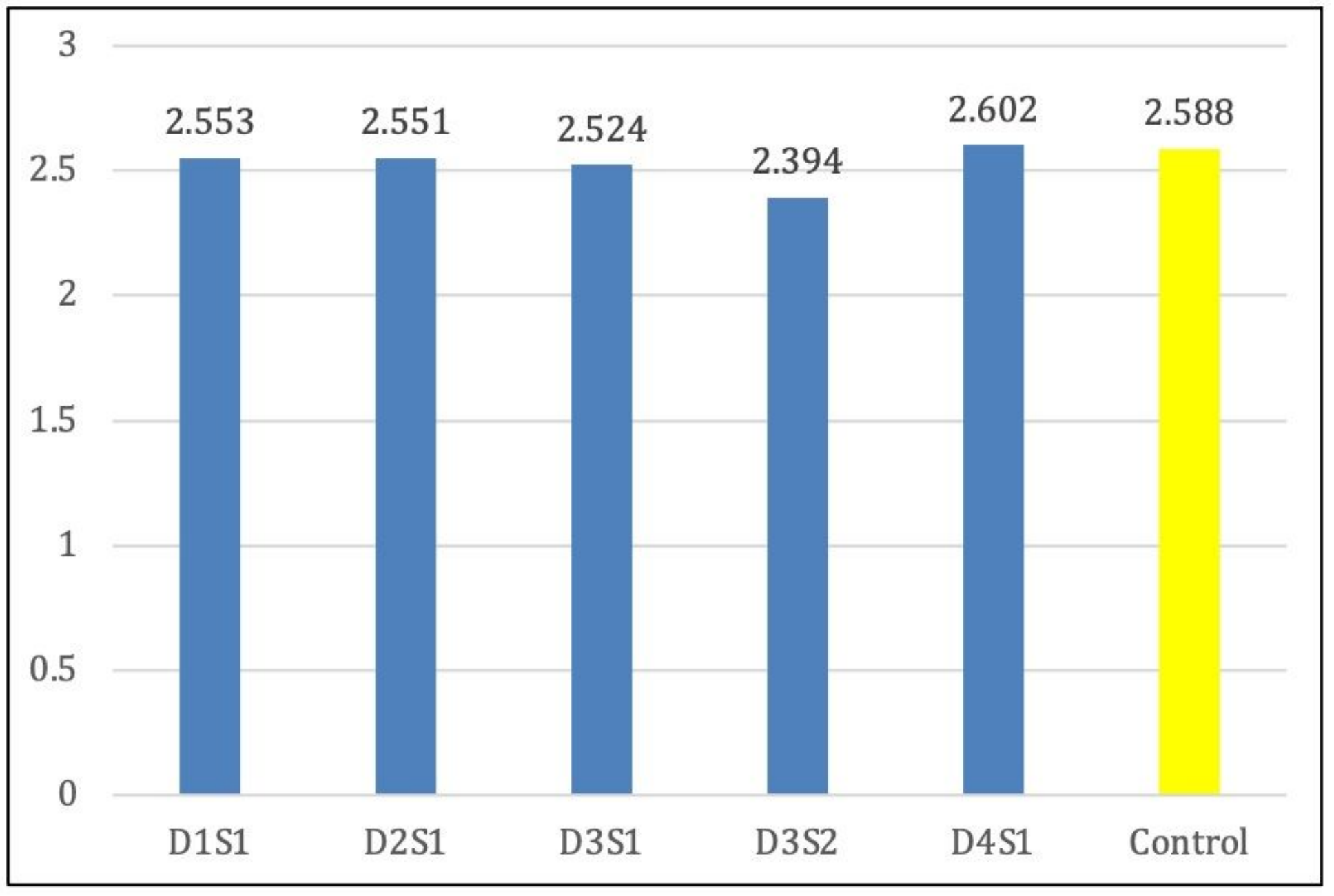

Figure 4

Rate of ureolysis of the species from the drip water of Bukilat Cave, Camotes Islands, Cebu and the positive control, B. megaterium. 


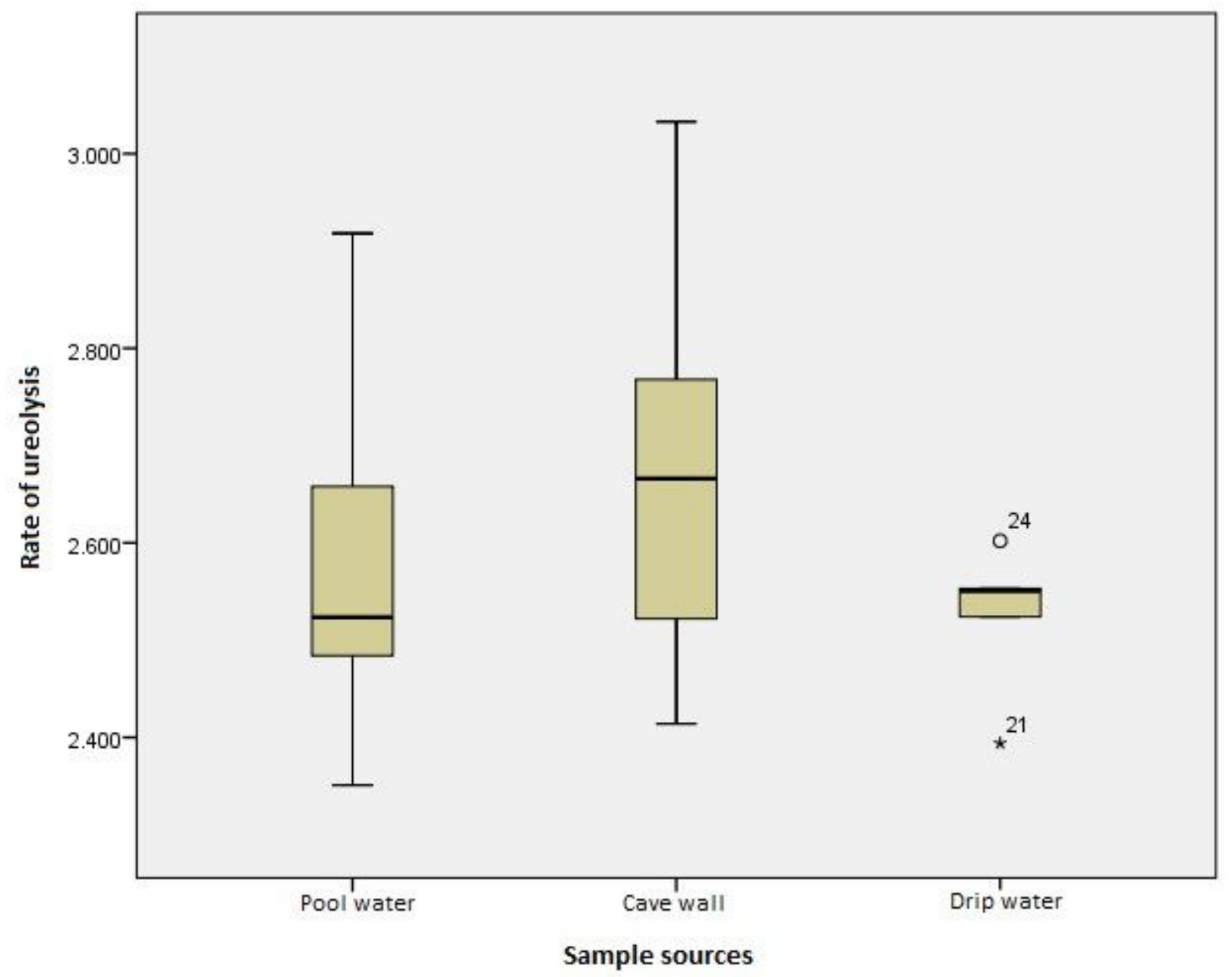

Figure 5

Distribution of urea hydrolyzed by the bacteria from each source. 